\title{
Preface-long-term ecosystem research: understanding the present to shape the future
}

\author{
Marcus Schaub • Matthias Dobbertin • \\ Norbert Kräuchi • Michèle Kaennel Dobbertin
}

Received: 28 September 2010 / Accepted: 29 September 2010 / Published online: 4 November 2010

(C) Springer Science+Business Media B.V. 2010

This special section of Environmental Monitoring and Assessment presents peer-reviewed contributions from the international conference "Long-term ecosystem research: Understanding the present to shape the future" that was held on 7-11 September 2009 in Zürich, Switzerland at the occasion of the 15th anniversary of the Swiss Long-Term Forest Ecosystem Research LWF. Since 1994, the Swiss Long-Term Forest Ecosystem Research Programme has been addressing global change as a driving force on forest biota and ecological processes. On this landmark date, the international community was invited to reflect on the current state of long-term (forest) ecosystem research and its scientific value.

The selected papers compiled in the present special issue highlight important insights into the latest aspects of long-term ecosystem research. Graf Pannatier et al. (2010) demonstrate the great value of the monitoring data from Swiss Level II

M. Schaub $(\varangle) \cdot$ M. Dobbertin · N. Kräuchi ·

M. K. Dobbertin

Swiss Federal Research Institute WSL,

Zürcherstrasse 111, 8903 Birmensdorf, Switzerland

e-mail: marcus.schaub@wsl.ch

Present Address:

N. Kräuchi

Departement Bau, Verkehr und Umwelt, Abteilung

Landschaft und Gewässer, Entfelderstrasse 22,

5001 Aarau, Switzerland plots within the framework of the International Co-operative Programme on Assessment and Monitoring of Air Pollution Effects on Forests (ICP-Forests). To assess the effects of air pollution abatements on acid deposition and the response of the soil solution chemistry, the authors investigated trends in acid deposition and in soil solution acidity for Switzerland.

Besides cation exchange capacity and various other soil indicators such as soil organic carbon, $\mathrm{pH}$, base saturation, soil bulk density, available water holding capacity, saturated hydraulic conductivity, etc., also biological indices such as the amount, activity and diversity of soil microorganisms have been used to assess changes in soil characteristics. Gömöryováa et al. (2010) focus on the responses of soil microorganisms to different management regimes on windthrow areas in the Tatra National Park in Slovakia. They show which microbial community characteristics best reflect changes in windthrow areas, depending on the management regime.

Ground vegetation is another powerful bioindicator to assess changes in the environment, as the species composition of a plant community reflects the ecological conditions at a given site and given time. Based on data from Swiss longterm forest ecosystem research sites, Thimonier et al. (2010) assessed ground vegetation during the period 1994-2003/2008. Their data revealed that repeated vegetation observations are important 
in studies that aim to assessing temporal changes over the long run. In particular, they emphasize the great need for continuous long-term monitoring data as the conclusions on the cause (here, either acidification or climatic conditions such as light) may differ depending on the time scale of the monitoring surveys.

Forested catchments are considered to guarantee a high quality of surface and drinking water. However, forests do not per se guarantee good water quality as stream acidification may still be a prevalent problem, particularly in catchments with bedrocks that are poor in base content. Based on trend analyses for 86 streams from various mountain ranges in Germany, Sucker et al. (2010) found that the investigated streams have responded in an unexpected rapid way to reduced anthropogenic deposition since the mid 1980s. The extent of recovery from acidification varies over time, between regions and between sites within regions, depending on a range of factors including the magnitude of deposition change and catchment characteristics. In general, streams with the highest deposition also had the largest observed changes in trends in stream water where sulfate desorption, organic S cycling in soils, and altered $\mathrm{N}$ cycling seem to be the most important influence factors.

Long-term data not only on deposition, climate, or plant- and soil-response but also on runoff are essential to draw firm conclusions about the behavior and trends of hydrological catchments that may be influenced by land-use and climate change (Stähli et al. 2010). Based on a 106-year data series, the longest continuous runoff records from two catchments in Switzerland (and possibly worldwide for catchments this size), the authors discuss the current and future (increasing) value of continuous long-term monitoring data, that may not be achieved by single, short-term case studies.

Embedding short-term experimental studies in a network of harmonized long-term monitoring plots may result in more effective research and management as well as better integration of local, national and global environmental policies in the near future. In this respect, we trust that this special issue will be a valuable source of information on demonstrating the essential value of long-term monitoring data. The urgent need of continuing such programs becomes evident when considering the increasing issues of ecosystem responses under the separate and combined influence of climate change, air pollution and land-use management.

The guest editors Marcus Schaub, Matthias Dobbertin, Norbert Kräuchi and Michèle Kaennel Dobbertin declare that they have no conflict of interest.

\section{References}

Gömöryováa, E., Střelcováa, K., Fleischerb, P., \& Gömörya, D. (2010). Soil microbial characteristics at the monitoring plots on windthrow areas of the Tatra National Park (Slovakia): their assessment as environmental indicators. Environmental Monitoring and Assessment. doi:10.1007/s10661-010-1755-2.

Graf Pannatier, E., Thimonier, A., Schmitt, M., Walthert, L., \& Waldner, P. (2010). A decade of monitoring at Swiss Long-term Forest Ecosystem Research (LWF) sites: can we observe trends in atmospheric acid deposition and in soil solution acidity? Environmental Monitoring and Assessment. doi:10.1007/ s10661-010-1754-3.

Stähli, M., Badoux, A., Ludwig, A., Steiner, K., Zappa, M., \& Hegg, C. (2010). One century of hydrological monitoring in two small catchments with different forest coverage. Environmental Monitoring and Assessment. doi:10.1007/s10661-010-1757-0.

Sucker, C., von Wilpert, K., \& Puhlmann, H. (2010). Acidification reversal in low mountain range streams of Germany. Environmental Monitoring and Assessment. doi:10.1007/s10661-010-1758-z.

Thimonier, A., Kull, P., Keller, W., Moser, B., \& Wohlgemuth, T. (2010). Ground vegetation monitoring in Swiss forests: comparison of survey methods and implications for trend assessments. Environmental Monitoring and Assessment. doi:10.1007/s10661010-1759-y. 